\title{
Identification of Tibicen cicada species by a Principal Components Analysis of their songs
}

\author{
EIJI OHYA \\ Biodiversity Research Group, Tohoku Research Center, Forestry and Forest Products Research Institute \\ Shimo-kuriyagawa aza Nabeyashiki 92-95, Morioka 020-0123, Japan
}

Manuscript received on January 15, 2004; accepted for publication on February 5, 2004.

\begin{abstract}
Specific identification of three Tibicen cicadas, T. japonicus, T. flammatus and T. bihamatus, by their chirping sounds was carried out using Principal Components Analysis (PCA). High quality recordings of each species were used as the standards. The peak and mean frequencies and the pulse rate were used as the variables. Out of 12 samples recorded in the fields one fell in the vicinity of T. japonicus and all other were positioned near T. bihamatus. Then the cluster analysis of the PCA scores clearly separated each species and allocated the samples in the same way.
\end{abstract}

Key words: cicada, Tibicen, Principal Components Analysis, sound, identification

\section{INTRODUCTION}

Japanese government and local authorities are now planning to make "green corridors", - forest connections between fragmented forest patches -, which allow animals to move from one patch to another and maintain their gene diversity (Miura 1999). The songs of Tibicen cicadas were used to survey possible effects (e.g. local extinction or geographical variation) caused by the habitat fragmentation of patched forests in the Kitakami highlands, Iwate, Japan.

There are three Tibicen species in the north of the main island: T. japonicus inhabits comparatively lower forests (about 500-1000 m) composed of Red Pine Pinus densiflora or Sugi Cedar Cryptomeria japonica as well as of other deciduous trees; T. flammatus is localized in higher forests (about 600-1200 m) composed of a variety of deciduous trees such as Beech Fagus crenata, Birch Betula

E-mail: ejoy@ffpri.affrc.go.jp tauschii and Oak Quercus mongolina; and T. bihamatus lives in much higher forests (about 900$1500 \mathrm{~m}$ ) composed of various deciduous or coniferous trees, mainly Beech (Hayashi 1984). The adults of these three species are present in July, August and September. Thus both their temporal and spatial niches overlap.

Since they usually sing on higher parts of the tree, their capture is difficult and thus the specific identification by means of their sounds is very useful. Since all of these three Tibicen species produce similar buzzing sounds, however, it is difficult to discriminate among them by ear. Therefore, a Principal Components Analysis of the sound was used to aid identification.

\section{MATERIALS AND METHODS}

The recordings were made during July and August in 2001 and 2002. When the weather was fine and warm, I drove through the forest slowly, carefully listening to the sounds outdoor, and if I detected 
TABLE I

Peak and mean frequencies and number of pulses in the songs of Tibicen specimens and species.

\begin{tabular}{c|c|c|c}
\hline Samples & $\begin{array}{c}\text { Peak frequency } \\
(\mathrm{Hz})\end{array}$ & $\begin{array}{c}\text { Mean frequency } \\
(\mathrm{Hz})\end{array}$ & $\begin{array}{c}\text { No. of pulses } \\
\text { per 0.2s }\end{array}$ \\
\hline 1 & 5220.7 & 5072.2 & 8 \\
2 & 6325.0 & 6295.0 & 17 \\
3 & 6355.9 & 6570.9 & 19 \\
4 & 6335.8 & 6397.8 & 20 \\
5 & 6348.0 & 6284.8 & 19 \\
6 & 6728.6 & 6635.9 & 19 \\
7 & 6414.7 & 6642.9 & 19 \\
8 & 6208.1 & 6181.5 & 17 \\
9 & 6356.5 & 6249.6 & 20 \\
10 & 5979.5 & 6151.4 & 19 \\
11 & 5724.6 & 6290.5 & 19 \\
12 & 6891.8 & 6609.5 & 20 \\
\hline T. japonicus & 5012.8 & 5354.3 & 9 \\
T. flammatus & 4730.0 & 4892.9 & 15 \\
T. bihamatus & 6104.9 & 6195.3 & 19 \\
\hline
\end{tabular}

any song, which seemed to be of Tibicen, I stopped the car and recorded it. The sounds were recorded by a minidisc recorder (Sony MZ-R90) with an electret condenser microphone (Sony ECM-MS907) and then processed by a PC with the Avisoft SASLab Pro software package. Principal Components Analysis was carried out using the peak and mean frequencies and the pulse rate as the variables. High quality recordings of each species (Matsuura 1986) were used as the standards.

\section{RESULTS AND DISCUSSION}

Table I shows the results for 2002 comparing with Matsuura's recordings as the standard. I recorded 22 samples from different locations in the Kitakami highland. In some recordings, however, the S/N ratio was too low, and in other examples, so many individuals sang together that it was difficult to distinguish each pulse. As a result, only 12 samples were available for the Principal Components Analysis.
The mean frequency of \#1 was $5072.2 \mathrm{~Hz}$ and thus it seems to be of T. japonicus $(5354.3 \mathrm{~Hz})$ or T. flammatus $(4892.9 \mathrm{~Hz})$. On the other hand, the mean frequencies of others, from \#2 to \#12, seem to be that of T. bihamatus $(6195.3 \mathrm{~Hz})$.

Then, comparing the number of pulses per $0.2 \mathrm{~s}$, \#1 was again different from the others. That is, only \#1 had a pulse count as low as 8 , whilst the others had 17 to 20 pulses. Thus \#1 was probably $T$. japonicus which has 9 pulses per $0.2 \mathrm{~s}$ and the others T. bihamatus, with 19 pulses.

Considering a comparison of both the mean frequency and the number of pulses, \#1 is more likely to be T. japonicus and the others, T. bihamatus. This conclusion is supported by the fact that sample \#1 was recorded in a low pine forest at about $200 \mathrm{~m}$ a.s.l. and the others at the higher beech forests. Comparison of the recorded sample sounds with each standard recording by Matsuura (1986) also reinforced this supposition.

For verification, I carried out a Principal Com- 


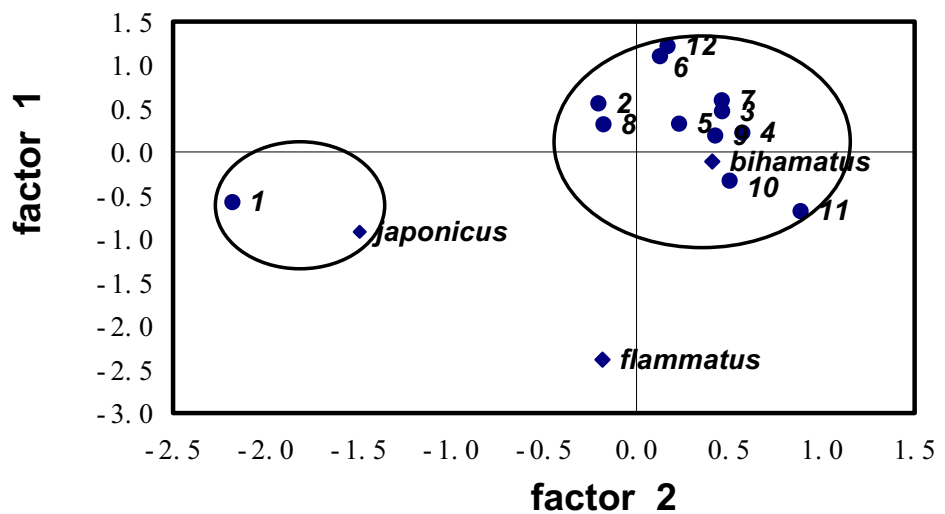

Fig. 1 - Principal Components Analysis of Tibicen species using the peak and mean frequencies and pulse rate as the variables.

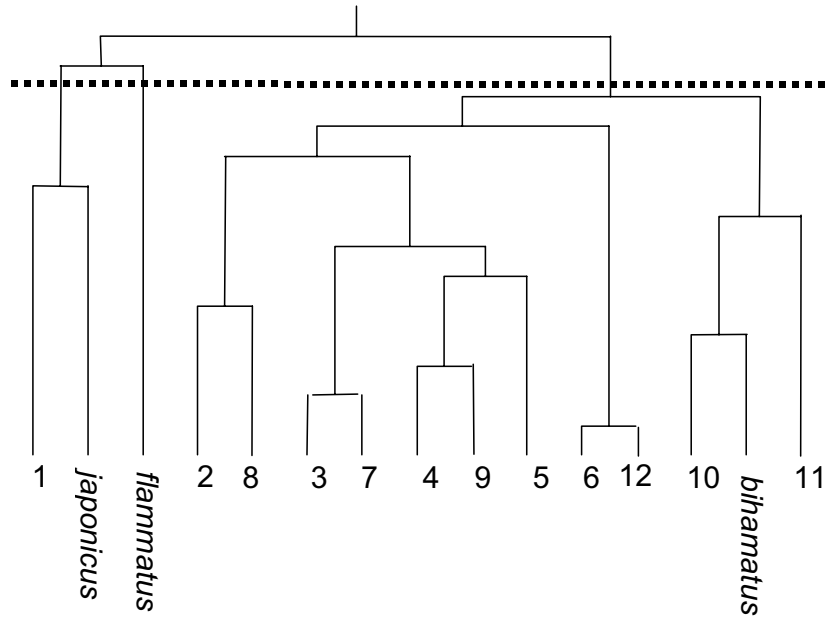

Fig. 2 - Dendrogram of the Tibicen species. The cluster analysis of the PCA scores clearly separated T. bihamatus, $T$. japonicus and $T$. flammatus from each other, and grouped the samples as they are expected to be.

ponents Analysis (Fig. 1) using the peak and mean frequencies and the pulse rate as the variables by means of a PC software package (ESUMI Co. Ltd.). All samples, except \#1, were positioned near T. bihamatus and the \#1 fell in the vicinity of $T$. japonicus as previously expected.

The cluster analysis of the PCA scores (Fig. 2) clearly separated T. japonicus, T. flammatus and $T$. bihamatus from each other and allocated the samples as expected. That is, \#1 was associated with $T$. japonicus and the others were grouped into $T$. bi- hamatus. When considering the forest type and the altitude where these sounds were recorded, this result seems reliable and the method promising. However, one should collect real specimens with each sound recording in order to check the result of this method.

\section{ACKNOWLEDGMENTS}

I am very grateful to Dr. Kinuura of FFPRI for his recording in 2002 in my absence. 


\section{RESUMO}

A identificação de três espécies de cigarras do gênero Tibicen, T. japonicus, T. flammatus e T. bihamatus, através de seus sons estridentes foi realizada por meio da Análise de Componentes Principais (PCA). Gravações de alta fidelidade de cada espécie foram usadas como referencias. As variáveis usadas foram as freqüências máxima e média e a taxa de pulsos. Das 12 amostras gravadas no campo, uma foi colocada perto de T. japonicus e as outras perto de T. bihamatus. A análise de conglomerados dos valores da PCA separou claramente cada espécie e posicionou as amostras da mesma maneira.
Palavras-chave: cigarras, Tibicen, Análise de Componentes Principais, som, identificação.

\section{REFERENCES}

Hayashi M. 1984. A Review of Japanese Cicadidae. Cicada 5: 25-75.

Matsuura H. 1986. Japanese Cicadas (CD). Tokyo: Natural Audio Laboratory.

Miura S. 1999. Wildlife and "The Green Corridor', Ringyo Gijutsu 691: 2-6. 